IBAD Sosyal Bilimler Dergisi

IBAD Journal of Social Sciences

dergipark.org.tr/ibad

IBAD, 2022; (12): 211-230

DOI: 10.21733/ibad.993181

Özgün Araştırma / Original Article

\title{
Anadolu Lisesi Öğrencilerinin “Müzik Dinlemek" Ve “Şarkı Söylemek" Kavramlarına İlişkin Algıları: Metafor Analizi
}

\section{Perceptions of Anatolian High School Students About "Listening to Music" and "Sing a Song" Concepts: Metaphorus Analysis}

\author{
Elvan Karakoç ${ }^{*}$ \\ Hakan Aryol ${ }^{2}$ \\ $*$ Sorumlu yazar
Corresponding author
}

${ }^{1}$ Dr. Öğr. Üyesi, Çankırı Karatekin Üniversitesi, Türkiye Assist. Prof. Dr., Çankırı Karatekin University, Turkey elvankarakoc@karatekin.edu.tr

ORCID ID https://orcid.org/0000-0001-8417-5446

${ }^{2}$ Yüksek Lisans Öğrencisi, Çankırı Karatekin Üniversitesi, Türkiye Stu., Çankırı Karatekin University, Turkey

hakanaryol@gmail.com

ORCID ID https://orcid.org/0000-0003-0077-4578

Makale geliș tarihi / First received : 09.09.2021

Makale kabul tarihi / Accepted $\quad$ :17.10.2021

\section{Bilgilendirme / Acknowledgement:}

1- Araştırmacıların katkı oranları eşittir. Yazarların araştırma tasarımı (birinci yazar), alanyazın taraması (ağırlıklı ikinci yazar ve daha az birinci yazar), veri toplama (ikinci yazar), veri analizi (ikinci yazar), makaleyi yazma (birinci yazar ve ikinci yazar), makaleyi dergiye sunma (birinci yazar) gibi katkıları vardır.

2- Uygulamaya katılan Burhaniye Anandolu Lisesi öğrencilerine teşekkür ederiz.

3- Makalenin yazarları arasında çıkar çatışması bulunmamaktadır.

4- Araştırmada kullanılan görüşme formunu öğrencilere uygulayabilmek için Burhaniye Kaymakamlığ İlçe Milli Eğitim Müdürlüğünden (Tarih:24.04.2021, Sayı:24536785) ile gerekli izinler alınmıştır. Çankırı Karatekin Üniversitesi Etik Kurulu değerlendirme kurulu tarafından (Tarih: 31.05.2021, Toplantı No:20) onay verilmiştir.

5- Bu makalede araştırma ve yayın etiğine uyulmuştur.

This article was checked by iThenticate. Similarity Index $21 \%$

\section{Atıf bilgisi / Citation:}

Karakoç, E. \& Aryol, H. (2022). Anadolu lisesi öğrencilerinin “müzik dinlemek" ve "şarkı söylemek" kavramlarına ilişkin algıları: Metafor analizi. IBAD Sosyal Bilimler Dergisi, (12), 211-230. 


\section{ÖZ}

Müzik; insanoğlu var olduğundan bu yana olduğu düşünülen, duygularımıza, sevinçlerimize, hüzünlerimize tercüman olan vazgeçilmez bir sanat dalıdır. Müzik dinlemek çoğu insan için vazgeçilmez bir unsur olarak düşünülse de şarkı söylemek kişiden kişiye değişiklik gösterebilir. Bu araştırmanın amacl, Anadolu lisesi öğrencilerinin müzik dinlemek ve şarkı söylemek kavramlarına ilişkin algılarını incelemek olarak belirlenmiştir. Öğrencilerin algıları metaforlar aracılığıyla incelenecektir. Araştırma betimsel bir çalışma olup, nitel araştırma yöntemlerinden, literatür tarama ve görüşme yöntemi kullanılmıştır. Elde edilen bu metaforların analizinde içerik analizi yöntemi kullanılmıştır. Çalışma grubunu Burhaniye Anadolu Lisesinde okumakta olan 150 öğrenci oluşturmaktadır. Elde edilen veriler sonucunda "müzik dinlemek" kavramına ilişkin 77, "şarkı söylemek kavramına ilişkin 89 geçerli metafor elde edilmiştir. Bu metaforların ortak yönleri ilişkilendirilerek, her kavram için 5 farklı kavramsal kategori belirlenmiştir. Kategorilerin, öğrencilerin cinsiyet, yaş ve sinıf düzeyine göre farklılığını ölçmek için pearson ki kare testi uygulanmış ve sonucunda anlamlı bir farklılık bulunmadığı ortaya çıkmıştır.

\section{ABSTRACT}

Music is an indispensable branch of art that has been thought to have existed since the existence of human beings and that interprets our emotions, joys and sorrows. Although listening to music is considered an indispensable element for most people, singing can vary from person to person. The aim of this study was to examine the perceptions of Anatolian high school students regarding the concepts of listening to music and singing. Students' perceptions will be examined through metaphors. The research is a descriptive study which used literature review and interview method from qualitative research methods. In the analysis of these metaphors obtained, content analysis methodh. The study group consists of 150 students studying at Burhaniye Anatolian High School. As a result of the data obtained, 77 valid metaphors for the concept of "listening to music" and 89 valid metaphors for the concept of "singing" were obtained. By associating the common aspects of these metaphors, 5 different conceptual categories were determined for each concept. Pearson chisquare test was applied to measure the differences in the categories according to the gender, age and grade level of the students, and it was found that there was no significant difference in the result.

\author{
Anahtar Kelimeler: \\ Müzik, Müzik Dinlemek, Şarkı Söylemek, Metafor \\ Analizi.
}

\section{Keywords}

Music, Listening to Music, Singing, Metaphor Analysis 


\section{GİRIŞ}

Müzik; insanoğlu var olduğundan bu yana olduğu düşünülen, duygularımıza, sevinçlerimize, hüzünlerimize tercüman olan ve eşlik eden vazgeçilmez bir sanat dalıdır. Müzik sadece, boş vakitlerimizde keyifle dinlediğimiz bir araç değil, sosyal ve kültürel birleştiriciliği olan sanat öğesidir. Sanat eğitimi ile yetişmiş, estetik beğenisi gelişmiş bireylerin kendilerine ve toplumlarına katkıları daha fazla olacaktır (Buyurgan vd. 2012, s. 5). Sanat eğitimi, gözlem yapma, orijinalite, buluş ve kişisel yaklaşımları destekler, pratik düşünceyi geliştirir. (Yolcu 2004, s. 91). Çocukların ve gençlerin herhangi bir sanat dalı ile ilgilenmeleri onların bilişsel, duyuşsal ve sosyal yönlerine büyük etkileri olduğu yapılan araştırmalarda ispatlanmıştır. Sanat eğitiminin önemli bir kolu olan müzik eğitimi ile kişiye kendini ifade etme, ilgilerini keşfetme, dinlemeyi öğrenme imkanı sağlanabilmektedir. Dinlemek yaşamın her alanında olduğu gibi müzik eğitiminde de önemli bir beceridir. Dinlemek TDK sözlükte işitmek, kulak vermek olarak tanımlanmıştır. Dinlemek belli bir amaç doğrultusunda yapılabileceği gibi dinlemede kişinin tercihine bağlı olarak, seçicilik de söz konusudur. (Aktaş vd. 2004, s. 247). Gençlerin dinledikleri müzikler, müzik tercihleri ile kişilikleri arasında bağ kurulabilir ve bunu gösteren pek çok araştırma yapılmıştır. Örneğin Martin vd. (1993, s. 535), gençlerin dinledikleri müzik türleri ve müzikteki mesajları inceleyen çalışmalarında kız grubun \%74' ünün pop, erkeklerin \%70. $7^{\prime}$ sinin rock/ metal müzik tercih ettiklerini ve bu müzik türlerinin gençlerde müziği dinledikten sonra üzgün hissetme, intihar, suçluluk, depresyon gibi duyguları tetiklediğini belirtmişlerdir. Gençlerle iletişim kurmak, onları anlamak için müzik bir araç olabilir. Müzik eğitiminde aktif olarak dinlemek, o anı yakalamak için dinlemek çok önemli bir beceridir (Martinez 2015, s. 14). Gençlerin dinledikleri ve tercih ettikleri müzikler üzerine Schwartz ve Foutz' un yaptıkları çalışmada, gençlerin müziği o anki ihtiyaçları doğrultusunda, ruh hallerine göre, bulundukları ortama göre esnek bir şekilde dinlemeyi tercih ettikleri saptanmıştır (Akt. Erdem 2011, s. 20). İlkokuldan ortaokul dönemine geçildiğinde, müzik dersi farklı özellikler taşımaya başlar. Müziğe ilgili gençler için, çalg1 öğrenmeye isteklilik, toplu şarkı söyleme alışkanlığından farklı olarak bireysel şarkı söyleme hevesinin ilk adımları atılmaya başlar. Müzik dinlemek çoğu insan için vazgeçilmez bir unsur olarak düşünülse de, şarkı söylemek kişiden kişiye değişiklik gösterebilir. Dil gelişimi, kişisel gelişim, sosyal gelişim gibi pek çok açıdan katkıları olan şarkı söylemeyi, Funch 2015 çalışmasında, çocuklar önce konuşmayı sonra şarkı söylemeyi öğrenirler olarak belirtmiştir (Akt. Yıldız vd. 2017, s. 497). Genel müzik eğitiminin verildiği okullarımızın, her kademesinde, öğrencilerin müzik dersine olan ilgileri ve algıları yapılan pek çok araştırmaya konu olmuştur. Algıların açıklanma ve yorumlanmasında nitel araştırma teknikleri içerisinde metaforlar, çok sık kullanılan bir yöntemdir. Kişilerin nasıl düşündüklerini, neler hissettiklerini, bakış açılarını keşfetmek adına metafor bir düşünme biçimi olarak kabul edilmektedir (Zheng vd. 2010, s. 42). Metaforlar bireylerin, soyut kavramlara ilişkin algılarını somut kavramlarla yer değiştirerek açıklamalarına olanak tanıyan güçlü ifade araçlarıdır (Uygun 2015, s. 2). Metafor kavramı, bir kelimeyi veya kavramı gerçek anlamından başka, ilgi veya benzetme sonucu kabul edilenin dışında başka anlamlara gelecek biçimde kullanma olarak tanımlanmaktadır (TDK 2011, s. 1641). Metaforları farklı araştırmacılar farklı şekillerde açıklamışlardır. Metaforları, (Cerit 2008, s. 6) kavramların nasıl algılandığını ortaya çıkarmaya katkı sağlar olarak belirtirken, (Kövecses 2010, s. 41) bireylerin bilişsel, tarih-kültürel birikimlerine göre metaforik kavramların anlaşılmasının da değişkenlik gösterebileceğini belirtmiştir. Metafor çoğu insan için şiirsel bir hayal gücü aracıdır (Lakoff vd. 1980, s. 3). Morgan'a göre (Morgan 1998, s. 14) metafor 
dünyamızı kavrayışımıza göre düşünme ve görme biçimidir. Eğitim alanında metafor tekniğiyle farklı birçok kavramın nasıl algılandığını belirlemek için pek çok araştırma yapıldığı gibi öğrencilerin bilişsel, duyuşsal ve kişilik gelişiminde önemli bir görev üstlenen müzik eğitimi dersinin de farklı eğitim ve yaş gruplarınca nasıl algılandığını anlamak için birçok araştırma yapılmıştır. Metaforlar, araştırmacıya çalışılan konu hakkında çok sağlam görsel bir imaj ve zengin bir resim sunmaktadır (Akt. Umuzdaş 2013, s. 721). Bu noktalardan hareketle, bu araştırmanın problem cümlesi "Anadolu Lisesi öğrencilerinin müzik dinlemek ve şarkı söylemek kavramlarına ilişkin algıları nasıldır?" olarak belirlenerek, aşağıdaki alt problemlere yanit aranacaktır.

1. Anadolu Lisesi öğrencilerinin "müzik dinlemek" kavramına ilişkin belirttikleri metaforlar nelerdir?

2. "Müzik dinlemek" kavramına ilişkin olan metaforların ortak özellikleri açısından belirlenen kavramsal kategorileri nelerdir?

3. Anadolu Lisesi öğrencilerinin "şarkı söylemek" kavramına ilişkin belirtikleri metaforlar nelerdir?

4. "Şarkı söylemek" kavramına ilişkin olan metaforların ortak özellikleri açısından belirlenen kavramsal kategorileri nelerdir?

5. Belirlenen kavramsal kategoriler öğrencilerin yaşı, sınıfı ve cinsiyeti açısından farklılık göstermekte midir?

\section{Amaç}

Bu araştırmanın amacl, Anadolu Lisesi öğrencilerinin "müzik dinlemek" ve "şarkı söylemek" kavramlarına ilişkin algılarını incelemektir. Öğrencilerin bu kavramlara ilişkin algıları metaforlar aracılığı ile belirlenmiştir. Öğrencilerin "müzik dinlemek" ve "şarkı söylemek" kavramlarına ilişkin algılarının betimlenmesi ve yorumlanması ile genel müzik eğitimi alanında müzik dersinin niteliğinin artmasını sağlamak açısından araştırmanın önem taşıdığı düşünülmektedir.

\section{İlgili Araştırmalar}

Çetinkaya Y. (2019), müzik bölümü öğrencilerinin müzik kavramına ilişkin metaforik algıları adlı çalışmasında, müzik kavramına ilişkin öğrencilerin ürettikleri 70 geçerli metafor 3 ana kategoride toplanmış, bu ana kategorileri de kendi içinde 12 alt kategoriye ayırmıştır. 70 metafordan 35'i müziği bir uğraş/meslek olarak algılama yönünde yoğunlaşmış ve müziğin özgürlük gerektiren bir alan olduğu algısında birleşmiş olduğu görülmüştür.

Düzgören, H., Gerekten, S. E. (2017), Anadolu lisesi öğrencilerinin 'müzik dersi' kavramına ilişkin algılarını metaforlar aracılığıyla incelemeyi amaçladığı çalışmasında, öğrenciler 94 geçerli metafor üretmiş, bu metaforlar 8 farklı kavramsal kategori altında toplanmıştır. Öğrencilerin, müzik dersini daha çok Hayat', 'Yemek', 'Aşk', 'Nefes 'metaforları ile ifade ettikleri görülmüştür.

Tez İ. (2016), ortaokul öğrencilerinin müzik, müzik dersi ve müzik öğretmeni kavramlarına ilişkin algılarının metaforlar aracılığıyla incelemesi adlı çalışmasında, müzik kavramına 160 adet, müzik dersi kavramına ilişkin 278 adet ve müzik öğretmeni kavramına ilişkin de 195 adet metafor ürettikleri belirlenmiştir. Her bir boyut için üretilen metaforlar ortak özellikleri 
bakımından incelenerek, müzik kavramına 15, müzik dersi kavramına 12, müzik öğretmeni kavramına ilişkin 15 farklı kavramsal kategori altında toplanmıştır. Çalışmanın çok yönlü bir özellik taşıdığı sonucuna ulaşılmıştır.

Zembat R., Tunçeli İ. H., Akşin E. (2015) çalışmalarında, okul öncesi öğretmen adaylarının okul yöneticisi kavramına ilişkin algılarını metaforlar aracılığıyla belirlemeyi amaçladığı çalışmasında, öğretmen adaylarının algılarının en çok Baba (16), Lider (8), Anne (7), Ebeveyn (6) metaforlarıyla özdeşleştirdiği görülmüş ve kategori dağılımına bakıldığında “okul yöneticisini" öğrencilerini ve öğretmenlerini koruyan, kollayan, problem çözen, yol gösteren kişiler olarak yani çoğunlukla olumlu olarak algıladıkları görülmüşsür.

Babacan E. (2014) Anadolu Güzel Sanatlar Lisesi müzik öğrencilerinin "müzik" kavramına ilişkin algılarını metaforlar aracılığıyla incelemeyi amaçladığı çalışmasında, öğrencilerin ürettikleri 99 adet geçerli metafor, 9 farklı kategoride toplanmış, yaş, cinsiyet ve sınıf düzeyine göre karşılaştırıldığında farklılık bulunmamıştır.

Saban A. (2008) "Okula ilişkin Metaforlar" adlı çalışmasında, ilköğretim birinci kademe öğrenci, öğretmen ve öğretmen adayları okul kavramına ilişkin olarak toplam 74 adet geçerli metafor üretmiştir. Bu metaforlar daha sonra ortak özellikleri bakımından irdelenerek 10 farklı kavramsal kategori altında toplanmıştır. Söz konusu bu 10 kavramsal kategori katılımcı türü (öğrenci, öğretmen ve öğretmen adayı) bakımından önemli derecede farklılık gösterdiği görülmüştür.

\section{YÖNTEM}

\section{Araştırmanın Modeli}

Araştırma, var olan bir durumu ortaya koymaya yönelik betimsel bir çalışmadır. Nitel araştırma yöntemleri kullanılmıştır. Nitel araştırma yöntemlerinden, literatür tarama ile açıklanan kuramsal çerçeve, görüşme formuyla toplanan verilerdeki metaforlar içerik analizi ile çözümlenerek, sayısal verilerle birlikte desteklenmiştir. İçerik analizinde toplanan verilerin önce kavramsallaştırılması bu kavramların mantıklı şekilde organize edilmesi ve verileri açıklayan temaların saptanması gerekmektedir (Yıldırım ve Şimşek, 2000, s. 160).

\section{Çalışma Grubu}

Bu araştırma, 2020-2021 eğitim-öğretim ikinci döneminde Burhaniye Anadolu Lisesinde eğitim gören 154 öğrencinin katılımıyla gerçekleşmiştir. Ancak eleme işleminde geçersiz veriler çıkarıldıktan sonra veri analizi işlemine 150 öğrenci dahil edilmiştir. Katılımcıların yaş ve sınıf dağılımları şöyledir:

Tablo 1. Anadolu Lisesi Öğrencilerinin Demografik Özellikleri

\begin{tabular}{|c|c|c|c|c|c|c|c|c|}
\hline Cinsiyet & f & $\%$ & Sinif & $\mathrm{f}$ & $\%$ & Yaş & f & $\%$ \\
\hline Erkek & 59 & 39,3 & 9.Sinif & 40 & 26,7 & 14 & 7 & 4,7 \\
\hline \multirow[t]{4}{*}{$\mathrm{K}_{1 z}$} & 91 & 60,7 & 10.Sinif & 34 & 22,7 & 15 & 40 & 26,7 \\
\hline & & & 11.Sinif & 53 & 35,3 & 16 & 39 & 26,0 \\
\hline & & & 12.Sinif & 23 & 15,3 & 17 & 48 & 32,0 \\
\hline & & & & & & 18 & 16 & 10,7 \\
\hline Toplam & 150 & 100,0 & Toplam & 150 & 100,0 & Toplam & 150 & 100,0 \\
\hline
\end{tabular}


Tablo 1'de görüldüğü gibi, çalışma grubu \%39,3 erkek, \%60,7'si kız öğrencilerden oluşmaktadır.

\section{Verilerin Toplanması}

Araştırmada, Burhaniye Anadolu Lisesinde eğitim gören 150 öğrenciden, "müzik dinlemek" ve "şarkı söylemek" kavramları ile ilgili metafor üretmeleri istenmiştir. Öğrencilerinin "müzik dinlemek" ve "şarkı söylemek" kavramlarına ilişkin algılarını ortaya çıarmak için online ortamda olacak şekilde bir form hazırlanmıştır. Araştırmada kullanılan görüşme formunu öğrencilere uygulayabilmek için Burhaniye Kaymakamlı̆̆ İlçe Milli Eğitim Müdürlüğünden (Tarih:24.04.2021, Sayı:24536785) ile gerekli izinler alınmıştır. Çankırı Karatekin Üniversitesi Etik Kurulu değerlendirme kurulu tarafından (Tarih: 31.05.2021, Toplantı No:20) ile onay verilmiştir. Oluşturulan formun ilk bölümünde öğrencilerin yaş, cinsiyet ve sinıfları sorulmuş, ikinci bölümünde ise öğrencilerden "Müzik dinlemek...gibidir; çünkü..., şarkı söylemek...gibidir; çünkü..." cümlelerini tamamlamaları istenmiştir. Alanyazın çalışmaları incelendiğinde (Babacan, 1994; Balc1, 1999; Çetinkaya 2019; Inbar, 1996; Örücü, 2012; Saban, 2008; Umuzdaş ve Umuzdaş, 2013) katılımcıya yazılı bir ifade vererek aradaki boşluğu doldurmalarının istenmesi, metafor çalışmalarında veri elde etmek için sıklıkla kullanılan yöntemlerden biridir. Metafor çalışmalarında 'gibi' kavramı genellikle metaforun konusu ile metaforun kaynağı arasındaki bağı daha açık bir şekilde çağrıştırmak için, çünkü kavramı ise sunulan metaforlara bir gerekçe (veya mantıksal dayanak) sunmaları için istenmektedir. (Saban, 2009, s. 285). Öğrencilerin online ortamda doldurdukları bu formlar doküman olarak araştırmanın veri kaynağını oluşturmaktadır.

\section{Verilerin Analizi}

Toplanan verileri, açıklayabilecek kavramlara ulaşabilmek için içerik analiz yöntemi kullanılmıştır. Araştırmanın nitel veri analizinde öğrencilerin, cinsiyet, sınıf ve yaş aralıkları ile elde edilen metaforların ve oluşturulan kategorilerin SPSS istatistik programına aktarılmasıyla elde edilen verilerin yüzde ve frekansları alınarak tablolaştırılmış ve öğrencilerin cinsiyet, yaş ve sınıf düzeyine göre farklılığı yorumlanmıştır. Verilerin, analiz edilmesi ve yorumlanması sürecinde şu aşamalar dikkate alınmıştır: (1) metaforların kodlanması ve ayıklanması, (2) metaforların sınıflandırılması, (3) kategori geliştirme, (4) geçerlik ve güvenirliği sağlama ve (5) nicel veri analizi için verileri SPSS paket programına aktarma (Saban, 2008, s. 464). Öğrenciler tarafından üretilen metaforlar, alfabetik olarak sıralanmıştır. Üretilen metaforların mantıksal dayanağı çerçevesinde belirgin olup olmadığına bakılması sonucu uygun olmayanlar elenerek çalışmaya dahil edilmemiştir. 154 kişinin katıldığı çalışmadan boş form ve mantıksal olarak uygun bulunmaması sonucu 4 formun çıkartılması ile çalışmaya 150 metafor dahil edilmiştir. Bu doğrultuda, "Müzik dinlemek.....gibidir" kavramına ilişkin 77 tane geçerli metafor, "Şark1 söylemek.....gibidir" kavramına ilişkin de 89 tane geçerli metafor üretilmiştir. Sınıflandırma aşamasında toplamda 166 adet geçerli metafor belirli bir kategori altında toplanıp benzer özellikleri analiz edilmiş ve 2 ayrı metafor listesi oluşturulmuştur. Daha sonra her iki kavram için ayrı ayrı düşünülmek suretiyle metaforun konusu ile metaforun kaynağı arasındaki ilişki bakımından analiz edilerek metaforların ortak yönleri ile ilişkilendirilip iki listeden elde edilen veriler ışığında her bir kavram için ayrı kavramsal kategori tablosu oluşturulmuştur. Her bir kavram için 5 farklı kavramsal kategori belirlenmiştir. Nitel çalışmalarda araştırmacının sonuçlara nasıl ulaştığını ayrıntılı bir şekilde rapor edip açıklaması geçerliğin önemli ölçütleri arasında yer almaktadır (Yıldırım, 2010, s. 81-82). Araştırmanın geçerlik güvenirliğini 
sağlamak için öğrencilerin "çünkü..." açıklamasına yazdıkları tamamlayıcı cümleler ile veri analizleri karşılaştırılıp oluşturulan kavramsal kategori metafor imgeleriyle desteklenmiştir. İçerik analizi işleminin güvenirliği büyük ölçüde kodlamaya bağlıdır. Bu ise kodlayıcının temalama güvenirliğiyle ilgilidir (Bilgin, 2006, s. 16). Alınan verilerin analiz işlemleri, güvenirliğinin teyidi bakımından üç gün ara ile iki kez tekrarlanarak kontrol edilmiştir. Daha sonra alanda çalışan bir öğretim üyesinin, metafor listesini ve kavramsal kategorileri incelemesi sağlanmıştır. Son aşama olarak araştırmanın nitel veri analizinde öğrencilerin, cinsiyet, sınıf ve yaş aralıkları ile elde edilen metaforların ve oluşturulan kategorilerin SPSS istatistik programına aktarılmasıyla elde edilen verilerin yüzde ve frekansları alınarak tablolaştırılmıştır. Kategorilerin, öğrencilerin cinsiyet, yaş ve sınıf düzeyine göre farklılığını ölçmek için pearson ki kare testi uygulanmış sonuçları yorumlanmıştır.

\section{BULGULAR}

Bu bölüm, araştırmanın amacına yönelik olarak belirlenen alt problemlere göre incelenecektir. Öğrencilerin belirtikleri metaforlar alfabetik sira ve yüzde (\%), frekans (f) değerleriyle gösterilecektir.

\section{Anadolu Lisesi öğrencilerinin "müzik dinlemek" kavramına ilişkin belirttikleri metaforlar}

Tablo 2. "Müzik dinlemek" kavramına ilişkin metaforlar

\begin{tabular}{|c|c|c|c|c|c|c|c|}
\hline ڤี & Metafor Adı & 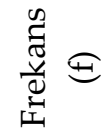 & 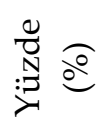 & कٌ & Metafor Ad1 & 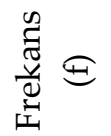 & 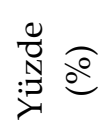 \\
\hline 1 & Aidiyet & 2 & 1,3 & 40 & Okyanus & 1 & 0,7 \\
\hline 2 & Arkadaş & 1 & 0,7 & 41 & Oyun & 1 & 0,7 \\
\hline 3 & Aşk & 1 & 0,7 & 42 & Oyun oynama & 1 & 0,7 \\
\hline 4 & Başka bir evrene geçiş & 1 & 0,7 & 43 & Özgürlük & 1 & 0,7 \\
\hline 5 & Başrol olmak & 1 & 0,7 & 44 & Psikiyatrik destek & 1 & 0,7 \\
\hline 6 & Canlilık & 1 & 0,7 & 45 & Rahatlamak & 6 & 4,0 \\
\hline 7 & Çay içmek & 1 & 0,7 & 46 & Rahatlık & 1 & 0,7 \\
\hline 8 & Çikolata & 1 & 0,7 & 47 & Ruh hali & 1 & 0,7 \\
\hline 9 & Dalış yapmak & 1 & 0,7 & 48 & Ruh dinlendirmek & 2 & 1,3 \\
\hline 10 & Deniz & 1 & 0,7 & 49 & Ruhsal ilaç & 1 & 0,7 \\
\hline 11 & Dinlenmek & 6 & 4,0 & 50 & Ruhu beslemek & 1 & 0,7 \\
\hline 12 & Dost & 1 & 0,7 & 51 & Ruhu dinlendirmek & 1 & 0,7 \\
\hline 13 & Dostluk & 1 & 0,7 & 52 & Ruhumuzun dans etmesi & 1 & 0,7 \\
\hline 14 & Dünyama işınlanmak & 1 & 0,7 & 53 & Ruhumuzun Doktoru & 1 & 0,7 \\
\hline 15 & Etkileşim & 1 & 0,7 & 54 & Ruhun g1dası & 5 & 3,3 \\
\hline 16 & Evren & 2 & 1,3 & 55 & Ruhun sanatı & 1 & 0,7 \\
\hline 17 & Film izlemek & 1 & 0,7 & 56 & Sağlık & 2 & 1,3 \\
\hline 18 & Güzel bir manzara & 1 & 0,7 & 57 & Sahilde yürümek & 1 & 0,7 \\
\hline 19 & Hayal kurmak & 3 & 2,0 & 58 & Sakinleşmek & 1 & 0,7 \\
\hline 20 & Hayat & 8 & 5,3 & 59 & Sanat & 1 & 0,7 \\
\hline 21 & Hayattan uzaklaşmak & 2 & 1,3 & 60 & Sarılmak & 1 & 0,7 \\
\hline
\end{tabular}


Anadolu Lisesi Öğrencilerinin “Müzik Dinlemek” Ve “Şarkı Söylemek” Kavramlarına İlişkin Algıları: Metafor Analizi

\begin{tabular}{llllllll}
\hline 22 & Hissetmek & 1 & 0,7 & 61 & Seyahat etmek & 1 & 0,7 \\
\hline 23 & Huzur & 9 & 6,0 & 62 & Su & 2 & 1,3 \\
\hline 24 & Huzur bulmak & 1 & 0,7 & 63 & Tatil & 1 & 0,7 \\
\hline 25 & Huzur verici & 1 & 0,7 & 64 & Tatile çımak & 1 & 0,7 \\
\hline 26 & İhtiyaç & 1 & 0,7 & 65 & Terapi & 17 & 11,3 \\
\hline 27 & İlaç & 3 & 2,0 & 66 & Uyumak & 7 & 4,7 \\
\hline 28 & Kaçmak & 1 & 0,7 & 67 & Ülke gezmek & 1 & 0,7 \\
\hline 29 & Kafa dağıtmak & 1 & 0,7 & 68 & Yağmur & 1 & 0,7 \\
\hline 30 & Kalbinin konuşması & 1 & 0,7 & 69 & Yalnılılk & 1 & 0,7 \\
\hline 31 & Kendini bulmak & 1 & 0,7 & 70 & Yaşam & 1 & 0,7 \\
\hline 32 & Kendini dinlemek & 1 & 0,7 & 71 & Yaşam biçimi & 1 & 0,7 \\
\hline 33 & Keyiftir & 1 & 0,7 & 72 & Yaşam tarzı & 1 & 0,7 \\
\hline 34 & Lunapark & 1 & 0,7 & 73 & Yaşamak & 3 & 2,0 \\
\hline 35 & Meditasyon & 1 & 0,7 & 74 & Yemek & 1 & 0,7 \\
\hline 36 & Motivasyon & 1 & 0,7 & 75 & Yemek yemek & 4 & 2,7 \\
\hline 37 & Mutluluk & 5 & 3,3 & 76 & Yoga & 1 & 0,7 \\
\hline 38 & Nefes & 2 & 1,3 & 77 & Yolu izlemek & 1 & 0,7 \\
\hline 39 & Nefes almak & 3 & 2,0 & & & 150 & 100,0 \\
\hline & & & & & TOPLAM & \\
\hline
\end{tabular}

Tablo 2'de öğrencilerin "Müzik dinlemek...gibidir. Çünkü..." kavramına ilişkin 77 adet metafor belirttikleri görülmektedir. Bu metaforlar içerisinde en sık kullanılan, terapi $(\% 11,3)$, huzur $(\% 6,0)$, hayat $(\% 5,3)$, uyumak $(\% 4,7)$, dinlenmek $(\% 4,0)$ ve rahatlamak $(\% 4,0)^{\prime}$ metaforları olduğu görülmektedir.

\section{2. "Müzik dinlemek" kavramına ilişkin olan metaforların ortak özellikleri açısından belirlenen kavramsal kategoriler}

Tablo 3. "Müzik dinlemek" kavramına ilişkin metaforların alt kategorileri

Kategoriler

Metaforlar

Arkadaş (f:1), Aşk (f:1), Dost (f:1), Güzel bir manzara

(f:1), Hayal kurmak(f:3), Hissetmek (f:1), Huzur(f:9),

Huzur bulmak (f:1), Huzur verici (f:1), Keyiftir (f:1),

Mutluluk (f:5), Sahilde yürümek (f:1), Sarılmak (f:1),

Yağmur (f:1), Yolu İzlemek (f:1)
Frekans Yüzde

(f)

$(\%)$

1) Müzik dinlemek insana

huzur ve mutluluk verir.

Çay içmek (f:1), Çikolata (f:1), Hayat (f:8), İhtiyaç

(f:1), Nefes (f:2), Nefes almak (f:3), Sağlık (f:2), Su

29

19,3

(f:2), Yaşamak (f:3), Yemek (f:2), Yemek yemek (f:4)

Canlılık (f:1), Film İzlemek (f:1), Kafa dağıtmak (f:1),

Lunapark (f:1), Motivasyon (f:1), Okyanus (f:1),

3) Müzik dinlemek rahatlatıcı ve eğlencelidir.
Oyun (f:1), Oyun oynama (f:1), Sakinleşmek (f:1),

Seyahat etmek (f:1), Tatil (f:1), Tatile çımak (f:1),

Uyumak(f:7),

Ülke gezmek (f:1) 
4) Müzik dinlemek bir yaşam biçimidir.
Aidiyet(f:2), Başrol olmak (f:1), Dalış yapmak (f:1), Dünyama 1şınlanmak (f:1), Etkileşim (f:1), Kendini bulmak (f:1), Kendini dinlemek (f:1), Özgürlük (f:1), Sanat (f:1), Yalnızlık (f:1), Yaşam biçimi (f:1), Yaşam $\operatorname{tarz1}(\mathrm{f}: 1)$

Başka bir evrene geçiş (f:1), Deniz (f:1), Dinlenmek (f:6), Evren (f:2), Hayattan uzaklaşmak (f:2), İlaç (f:3), Kaçmak (f:1), Kalbinin konuşması (f:1), Meditasyon

5) Müzik dinlemek insanın ruhunu dinlendirir.

Ruhunuzun dans etmesi (f:1), Ruhunuzun doktoru (f:1), Ruhun gidası (f:5), Ruhun sanatı (f:1), Terapi (f:17), Yoga (f:1)

\section{TOPLAM}

Tablo 3'te, metaforların açıklama nedenlerine bağlı olarak düzenlenmesiyle 5 kavramsal kategoriye ayrıldığı görülmektedir. Kategoriler incelendiğinde, birbirlerine yakın anlamlı kavramlar olduğu görülmüş, fakat; "çünkü" ile başlayan açıklamalardan yola çıkıldığında öğrencilerin metafora farklı bakış açısıyla yaklaştıkları gözlemlenmiştir. Kavramsal kategoride toplanan metaforlar incelendiğinde, en yüksek oranda $(\% 38,7)$ "Müzik dinlemek insanın ruhunu dinlendirir" kategorisinde bulunmaktadır. Diğer kategoriler frekans oranlarına göre sirasıyla; "Müzik dinlemek insana huzur ve mutluluk verir" (\%19,3), "Müzik dinlemek bir temel ihtiyaçtır." (\%19,3), “Müzik dinlemek rahatlatıcı ve eğlencelidir" (\%14), "Müzik dinlemek bir yaşam biçimidir" (\%8,7), şeklinde olduğu görülmektedir. Aşağıda kavramsal kategorilerin her birinin betimsel analizi yapılacaktır.

\section{Kategori 1: "Müzik dinlemek insana huzur ve mutluluk verir."}

Bu kategoride, 29, öğrenci $(\% 19,3)$ tarafından, 'Müzik dinlemek insana huzur ve mutluluk verir.' ifadesiyle örtüşen 15 metafor tanımlanmıştır. Bu metaforlar: 'arkadaş (f:1), aşk (f:1), dost (f:1), güzel bir manzara (f:1), hayal kurmak (f:3), hissetmek (f:1), huzur (f:9), huzur bulmak (f:1), huzur verici (f:1), keyiftir (f:1), mutluluk (f:5), sahilde yürümek (f:1), sarılmak (f:1), yağmur (f:1), yolu izlemek (f:1)' şeklindedir. Frekans dağılımlarına baktığımızda en çok kullanılan metaforların; huzur, hayal kurmak, mutluluk olduğu görülmektedir. Aşağıda en çok kullanılan metaforlara, kayıtlı form sırasına göre betimsel olarak bir kaç örnek verilmiştir. Örneğin;

Ö 72: "Müzik dinlemek huzur gibidir. Çünkü; her şeyi bir kenara bırakırsın.”

Ö 13: "Müzik dinlemek huzur gibidir. Çünkü; insanın mutlu olmasını sağlar."

Ö 14: “Müzik dinlemek huzur gibidir. Çünkü; rahatlatıcı bir özelliği vardır.”

Ö 24: “Müzik dinlemek mutluluk gibidir. Çünkü; dans edip şarkı söyleriz.”

Ö 28: “Müzik dinlemek mutluluk gibidir. Çünkü; kötü şeyler aklından gider.”

Ö 38: "Müzik dinlemek hayal kurmak gibidir. Çünkü; her dinlediğim müzik beni farklı bir yere götürüyor zihnimde." 


\section{Kategori 2: “Müzik dinlemek bir temel ihtiyaçtır.”}

Bu kategoride, 29 öğrenci (\%19,3) tarafından, 'Müzik dinlemek bir temel ihtiyaçtır.' ifadesiyle örtüşen 11 metafor tanımlanmıştır. Bu metaforlar: 'çay içmek (f:1), çikolata (f:1), hayat (f:8), ihtiyaç, nefes (f:2), nefes almak (f:3), sağlık (f:2), su (f:2), yaşamak (f:3), yemek (f:2), yemek yemek (f:4) şeklindedir. Frekans dağılımlarına göre en çok kullanılan metaforların; hayat, yemek yemek, nefes almak, yaşamak olduğu görülmektedir. Aşağıda en çok kullanılan metaforlara, kayıtlı form sırasına göre betimsel olarak bir kaç örnek verilmiştir. Örneğin;

Ö 8: “Müzik dinlemek hayat gibidir. Çünkü; insanlar müzik dinlerken yeniden hayat bulur.”

Ö 138: “Müzik dinlemek hayat gibidir. Çünkü; müzik her yerdedir.”

Ö 63 : “Müzik Dinlemek yemek yemek gibidir. Çünkü; yemek yemek karnınızı, müzik dinlemek ise duygularınızı ve hislerinizi doyurur."

Ö 99: “Müzik dinlemek nefes almak gibidir. Çünkü; insan için gereklidir.

Ö 95: “Müzik dinlemek yaşamak gibidir. Çünkü; yaşamdan oluşur müzikler yaşanmışlı̆̆ı anlatır."

\section{Kategori 3: "Müzik dinlemek rahatlatıcı ve eğlencelidir."}

Bu kategoride, 21 öğrenci (\%14) tarafından, 'Müzik dinlemek rahatlatıcı ve eğlencelidir.' ifadesiyle örtüşen 14 metafor tanımlanmıştır. Bu metaforlar: 'Canlılık (f:1), Film İzlemek (f:1), Kafa dağıtmak (f:1), Lunapark (f:1), Motivasyon (f:1), Okyanus (f:1), Oyun (f:1), Oyun oynama (f:1), Sakinleşmek (f:1), Seyahat etmek (f:1), Tatil (f:1), Tatile çıkmak (f:1), Uyumak (f:7), Ülke gezmek (f:1)' şeklindedir. Frekans dağılımlarına göre en çok kullanılan metaforun uyumak olduğu görülmektedir. Aşağıda en çok kullanılan metaforlara, kayıtlı form sırasına göre betimsel olarak bir kaç örnek verilmiştir.

Örneğin; Ö 59: “Müzik dinlemek uyumak gibidir. Çünkü; zamanın nasıl geçtiğini anlayamayız."

Ö 57: “Müzik dinlemek lunapark gibidir. Çünkü; lunaparktaki gibi eğleniriz, içimize neşe dolar."

Ö 96: "Müzik dinlemek motivasyon gibidir. Çünkü; deşarj oluyorum."

Ö 139: “Müzik dinlemek tatile çıkmak gibidir. Çünkü; dinlediğim her şarkı beni başka bir yere götürür."

Ö 143 “Müzik dinlemek seyahat etmek gibidir. Çünkü; size uygun müzik sizi, siz nereyi hayal ederseniz oraya götürebilecek kadar güçlüdür."

\section{Kategori 4: "Müzik dinlemek bir yaşam biçimidir."}

Bu kategoride, 13 öğrenci (\%8,7) tarafından, 'Müzik dinlemek bir yaşam biçimidir.' ifadesiyle örtüşen 12 metafor tanımlanmıştır. Bu metaforlar: 'Aidiyet (f:2), Başrol olmak (f:1), Dalış yapmak (f:1), Dünyama işınlanmak (f:1), Etkileşim (f:1), Kendini bulmak (f:1), Kendini dinlemek (f:1), Özgürlük (f:1), Sanat (f:1), Yalnızlık (f:1), Yaşam biçimi (f:1), Yaşam tarzı (f:1)' şeklindedir. Frekans dağılımlarına göre en çok kullanılan metaforun Aidiyet olduğu görülmektedir. Aşağıda en çok kullanılan metafor ve bazılarına kayıtlı form sırasına göre betimsel olarak bir kaç örnek verilmiştir. Örneğin; 
Ö 31 : “Müzik dinlemek aidiyet gibidir. Çünkü; ne zaman müzik dinlesem kendimi o müziğin bir parçasıymışım gibi hissederim."

Ö 37 : “Müzik dinlemek dünyama ışınlanmak gibidir. Çünkü; kendi dünyamızı kendimiz yaratırız ve dinlemek istediğimiz müzikleri de kendimiz seçeriz."

Ö 60: “Müzik dinlemek etkileşim gibidir. Çünkü; müzik dinlerken farklı dil, tür, tarzları keşfederiz."

Ö 24 : “Müzik dinlemek sanat gibidir. Çünkü hem emek verilen hem de huzurlu, duygusal, neşeli olan tüm kavramları içerir.

Ö 53: “Müzik dinlemek başrol olmak gibidir. Çünkü; kendi arka fon müziğinize sahipsinizdir."

\section{Kategori 5: “Müzik dinlemek insanın ruhunu dinlendirir.”}

$\mathrm{Bu}$ kategoride en baskın metaforların olduğu kısımdan oluşmaktadır, 58 öğrenci $(\% 38,7)$ tarafından, 'Müzik dinlemek insanın ruhunu dinlendirir.' İfadesine öğrenciler 20 metafor tanımlamışlardır. Bu metaforlar 'başka bir evrene geçiş (f:1), deniz (f:1), dinlenmek (f:6), evren (f:2), hayattan uzaklaşmak (f:2), ilaç (f:3), kaçmak (f:1), kalbinin konuşması (f:1), meditasyon (f:1), psikiyatrik destek (f:1), rahatlamak (f:6), rahatlık (f:1), ruh hali (f:1), ruh dinlendirmek(f:2), ruhunuzun dans etmesi (f:1), ruhunuzun doktoru (f:1), ruhun gidası (f:5), ruhun sanatı (f:1), terapi (f:17), yoga (f:1)' şeklinde sıralanmıştır. Frekans dağılımlarına göre en çok kullanılan metaforların; terapi, rahatlamak, dinlenmek, ruhun gıdası olduğu görülmektedir. Aşağıda en çok kullanılan metaforlara, kayıtlı form sırasına göre betimsel olarak bir kaç örnek verilmiştir. Örneğin;

Ö 12 : "Müzik dinlemek rahatlamak gibidir. Çünkü; dinlerken stresimizi attığımız için müzik dinlemek rahatlamak gibidir."

Ö 40 : "Müzik dinlemek terapi gibidir. Çünkü; rahatlamak ya da hayatın verdiği stresleri atmaya yardım eder."

Ö 49: "Müzik dinlemek dinlenmek gibidir. Çünkü; müzik dinleyerek ruhumuzu dinlendiririz."

Ö 78: "Müzik dinlemek terapi gibidir. Çünkü; şarkı dinlerken müziğin ezgisi insanı rahatlatiyor."

Ö 124: “Müzik dinlemek başka bir evrene geçiş gibidir. Çünkü; beni düşüncelerimle baş başa bırakıyor ve bulunduğum ortamda değil daha güzel bir yerde mutlu ve huzurlu hissediyorum.

Ö 129: “Müzik dinlemek psikiyatrik destek gibidir. Çünkü; şarkı ruhumu dinlendirip kendimi daha iyi hissetmeme ve daha iyi düşünmeme yardımcı olur."

Ö 133 : “Müzik dinlemek ruhun gıdası gibidir. Çünkü; ne zaman müzik dinlesem kendimi o müziğin bir parçasıymışım gibi hissederim." 


\section{Anadolu Lisesi öğrencilerinin "şarkı söylemek" kavramına ilişkin belirtikleri metaforlar}

Tablo 4. "Şarkı söylemek" kavramına ilişkin metaforlar

\begin{tabular}{|c|c|c|c|c|c|c|c|}
\hline क्ष & Metafor Adı & 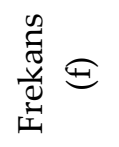 & 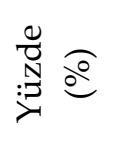 & के & Metafor Ad 1 & 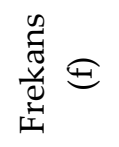 & 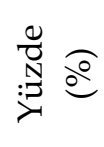 \\
\hline 1 & Anlaşılmak & 1 & 0,7 & 46 & Kalbinin dillenip konuşması & 1 & 0,7 \\
\hline 2 & Araba kullanmak & 1 & 0,7 & 47 & Kalp & 1 & 0,7 \\
\hline 3 & Araba sürmek & 1 & 0,7 & 48 & Kendin olmak & 1 & 0,7 \\
\hline 4 & Arınmak & 1 & 0,7 & 49 & Kendini geliştirmek & 1 & 0,7 \\
\hline 5 & Aşk & 1 & 0,7 & 50 & Kiyafet almak & 1 & 0,7 \\
\hline 6 & Cesaret & 1 & 0,7 & 51 & Konuşmak & 1 & 0,7 \\
\hline 7 & Coşku & 1 & 0,7 & 52 & Korkusuzluktur & 1 & 0,7 \\
\hline 8 & Coşmak & 1 & 0,7 & 53 & Kuş & 1 & 0,7 \\
\hline 9 & Çiçek & 1 & 0,7 & 54 & Lunapark & 1 & 0,7 \\
\hline 10 & Çikolata & 2 & 1,3 & 55 & Meditasyon & 5 & 3,3 \\
\hline 11 & $\begin{array}{l}\text { Yüksekten denize } \\
\text { atlamak }\end{array}$ & 1 & 0,7 & 56 & Mutlu olmak & 1 & 0,7 \\
\hline 12 & Dans etmek & 2 & 1,3 & 57 & Mutluluk & 3 & 2 \\
\hline 13 & Dertleşmek & 1 & 0,7 & 58 & Nefes almak & 3 & 2 \\
\hline 14 & Deşarj olmak & 1 & 0,7 & 59 & Oyun & 2 & 1,3 \\
\hline 15 & Deşarj & 1 & 0,7 & 60 & Oyun oynamak & 2 & 1,3 \\
\hline 16 & Dişa vurmak & 1 & 0,7 & 61 & Özgürleşmek & 2 & 1,3 \\
\hline 17 & Doğa yürüyüşü & 1 & 0,7 & 62 & Özgürlük & 14 & 9,3 \\
\hline 18 & Duyguları anlatmak & 1 & 0,7 & 63 & Özgüven & 1 & 0,7 \\
\hline 19 & Duygularımız & 2 & 1,3 & 64 & Paylaşmak & 1 & 0,7 \\
\hline 20 & Duyguları yansıtmak & 1 & 0,7 & 65 & Ruh & 6 & 4 \\
\hline 21 & $\begin{array}{l}\text { Duyguları dışa } \\
\text { haykırmak }\end{array}$ & 1 & 0,7 & 66 & Ruh Hali & 1 & 0,7 \\
\hline 22 & $\begin{array}{l}\text { Duygularını dışarı } \\
\text { vurmak }\end{array}$ & 1 & 0,7 & 67 & Ruhun gidası & 1 & 0,7 \\
\hline 23 & Duygularını haykırmak & 1 & 0,7 & 68 & Rüzgâr & 1 & 0,7 \\
\hline 24 & Duygularını ifade etmek & 1 & 0,7 & 69 & Sağlık & 1 & 0,7 \\
\hline 25 & Duyuları ifade etmek & 1 & 0,7 & 70 & Samimiyet & 2 & 1,3 \\
\hline 26 & Eğlence & 1 & 0,7 & 71 & Sanat yapmak & 1 & 0,7 \\
\hline 27 & Eğlenceli & 1 & 0,7 & 72 & $\begin{array}{l}\text { Sevinç veya sıkıntıları } \\
\text { paylaşma }\end{array}$ & 2 & 1,3 \\
\hline 28 & Eğlencelidir & 1 & 0,7 & 73 & Sevinmek & 1 & 0,7 \\
\hline 29 & Eğlenmek & 6 & 4 & 74 & Stres atma & 1 & 0,7 \\
\hline 30 & Gida & 1 & 0,7 & 75 & Stres atmak & 1 & 0,7 \\
\hline 31 & Gülümsemek & 1 & 0,7 & 76 & Şarkıcilık & 1 & 0,7 \\
\hline 32 & Hayal & 1 & 0,7 & 77 & Şifa kaynağ1 & 1 & 0,7 \\
\hline 33 & Hayal kurmak & 1 & 0,7 & 78 & Tablo yapmak & 1 & 0,7 \\
\hline 34 & Hayat & 2 & 1,3 & 79 & Terapi & 13 & 8,7 \\
\hline
\end{tabular}


Anadolu Lisesi Öğrencilerinin “Müzik Dinlemek” Ve “Şarkı Söylemek” Kavramlarına İlişkin Algıları: Metafor Analizi

\begin{tabular}{|c|c|c|c|c|c|c|c|}
\hline 35 & Haykırış & 1 & 0,7 & 80 & Tutku & 1 & 0,7 \\
\hline 36 & Haykırmak & 1 & 0,7 & 81 & Uçmak & 3 & 2 \\
\hline 37 & Hedonizm (hazcilık) & 1 & 0,7 & 82 & $\begin{array}{l}\text { Uçsuz bucaksız dağa } \\
\text { bağırmak }\end{array}$ & 1 & 0,7 \\
\hline 38 & Hüzün & 1 & 0,7 & 83 & Uyumak & 1 & 0,7 \\
\hline 39 & İçimizi dökmek & 1 & 0,7 & 84 & Vuruşların birleşmesi & 1 & 0,7 \\
\hline 40 & İçindekileri anlatmak & 1 & 0,7 & 85 & Yaşamak & 2 & 1,3 \\
\hline 41 & İçini dökmek & 5 & 3,3 & 86 & Yazmayı yeni öğrenen çocuk & 1 & 0,7 \\
\hline 42 & İlaç & 2 & 1,3 & 87 & Yemek & 2 & 1,3 \\
\hline 43 & İsyan etmek & 1 & 0,7 & 88 & Yürüyüş yapmak & 1 & 0,7 \\
\hline 44 & İyileşmek & 1 & 0,7 & 89 & Zevklidir & 1 & 0,7 \\
\hline \multirow[t]{2}{*}{45} & Kahkaha atmak & 1 & 0,7 & & & & \\
\hline & & & & & TOPLAM & 150 & 100,0 \\
\hline
\end{tabular}

Tablo 4 incelendiğinde, öğrencilerin "Şarkı söylemek...gibidir. Çünkü..." kavramına ilişkin 89 adet metafor ürettikleri görülmektedir. Bu metaforlar içerisinde en sık kullanılan, 'özgürlük $(\% 9,3)$, terapi $(\% 8,7)$, eğlenmek $(\% 4)$, ruh $(\% 4)$ ve içini dökmek $(\% 3,3)$, meditasyon $(\% 3,3)$ metaforlarıdır.

\section{4. "Şarkı söylemek" kavramına ilişkin olan metaforların ortak özellikleri açısından belirlenen kavramsal kategoriler}

Tablo 5. "Şarkı söylemek" kavramına ilişkin metaforların alt kategorileri

\begin{tabular}{|c|c|c|c|}
\hline Kategoriler & Metaforlar & $\begin{array}{c}\text { Frekans } \\
(\mathrm{f})\end{array}$ & $\begin{array}{c}\text { Yüzde } \\
(\%)\end{array}$ \\
\hline $\begin{array}{l}\text { 1) Şarkı söylemek insana } \\
\text { özgürlük hissi verir. }\end{array}$ & $\begin{array}{c}\text { Arınmak, Haykırış (f:1), Haykırmak (f:1), } \\
\text { Hedonizm (f:1), Kendin olmak (f:1), Kuş (f:1), } \\
\text { Nefes almak (f:3), Özgürleşmek (f:2), Özgürlük } \\
\text { (f:14), Sanat yapmak (f:1), Uçmak (f:3) }\end{array}$ & 29 & 19,3 \\
\hline $\begin{array}{l}\text { 2) Şarkı söylemek bir } \\
\text { rahatlama biçimidir. }\end{array}$ & $\begin{array}{c}\text { Dertleşmek (f:1), Deşarj olmak (f:1), Deşarj (f:1), } \\
\text { İçimizi dökmek (f:1), İçindekileri anlatmak (f:1), } \\
\text { İçini dökmek (f:5), İlaç (f:2), İsyan etmek (f:1), } \\
\text { İyileşmek (f:1), Meditasyon (f:5), Ruh (f:6), Ruh } \\
\text { hali (f:1), Ruhun gidası (f:1), Sağllk (f:1), Stres } \\
\text { atma (f:1), Stres atmak (f:1), Şifa kaynağı (f:1), } \\
\text { Uçsuz bucaksız dağa bağırmak (f:1), Uyumak (f:1), } \\
\text { Yürüyüş̧ yapmak (f:1) }\end{array}$ & 34 & 22,7 \\
\hline $\begin{array}{l}\text { 3) Şarkı söylemek insanın } \\
\text { duygularını yansıtır. }\end{array}$ & $\begin{array}{l}\text { Anlaşılmak (f:1), Aşk (f:1), Cesaret (f:1), Coşku } \\
\text { (f:1), Coşmak (f:1), Dışa vurmak (f:1), Duyguları } \\
\text { anlatmak (f:1), Duygularımız (f:2), Duyguları } \\
\text { yansıtmak (f:1), Duygularını dişa haykırmak (f:1), } \\
\text { Duygularını dışarı vurmak (f:1), Duygularını } \\
\text { haykırmak (f:1), Duygularını ifade etmek (f:1), } \\
\text { Duyuları ifade etmek (f:1), Hayal (f:1), Hayal } \\
\text { kurmak (f:1), Hayat (f:2), Hüzün (f:1), Kahkaha } \\
\text { atmak (f:1), Kalbinin dillenip konuşması (f:1), } \\
\text { Kalp (f:1), Kendini geliştirmek (f:1), Konuşmak } \\
\text { (f:1), Korkusuzluktur (f:1), Özgüven (f:1), Rüzgâr }\end{array}$ & 35 & 23,3 \\
\hline
\end{tabular}


(f:1), Samimiyet (f:2), Sevinç veya sıkıntıları paylaşmak (f:2), Sevinmek (f:1), Tablo yapmak

(f:1), Tutku (f:1)

\begin{tabular}{|c|c|c|c|}
\hline 4) Şarkı söylemek eğlencelidir. & $\begin{array}{c}\text { Araba kullanmak (f:1), Araba sürmek (f:1), } \\
\text { Yüksekten denize atlamak (f:1), Dans etmek (f:2), } \\
\text { Eğlence (f:1), Eğlenceli (f:1), Eğlencelidir (f:1), } \\
\text { Eğlenmek (f:6), Lunapark (f:1), Oyun (f:2), Oyun } \\
\text { oynamak (f:2), Şarkıcıllk (f:1), Vuruşların } \\
\text { birleşmesi (f:1), Yazmayı yeni öğrenen çocuk (f:1), } \\
\text { Zevklidir (f:1) }\end{array}$ & 23 & 15,3 \\
\hline \multirow[t]{2}{*}{$\begin{array}{l}\text { 5) Şarkı söylemek bizi mutlu } \\
\text { eder. }\end{array}$} & $\begin{array}{c}\text { Çiçek (f:1), Çikolata (f:2), Doğa yürüyüşü (f:1), } \\
\text { Gida (f:1), Gülümsemek (f:1), Kiyafet almak (f:1), } \\
\text { Mutlu olmak (f:1), Mutluluk (f:3), Paylaşmak (f:1), } \\
\text { Terapi (f:13), Yaşamak (f:2), Yemek (f:2) }\end{array}$ & 29 & 19,3 \\
\hline & TOPLAM & 150 & 100,0 \\
\hline
\end{tabular}

Tablo 5'de, metaforların açıklama nedenlerine bağlı olarak düzenlenmesiyle 5 kavramsal kategoriye ayrıldığı görülmektedir. Kategoriler incelendiğinde, birbirlerine yakın anlamlı kavramlar olduğu görülmüş, fakat; "çünkü" ile başlayan açıklamalardan yola çıkıldığında öğrencilerin metafora farklı bakış açısıyla yaklaştıkları gözlemlenmiştir. Kavramsal kategoride toplanan metaforlar incelendiğinde, en yüksek oranda (\%23,3) "Şarkı söylemek insanın duygularını yansıtır." kategorisinde bulunmaktadır. Diğer kategoriler frekans oranlarına göre sırasıyla; "Şarkı söylemek insana özgürlük hissi verir." (\%19,3), "Şarkı söylemek bir rahatlama biçimidir." (\%22,7), "Şarkı söylemek eğlencelidir." (\%15,3), "Şarkı söylemek bizi mutlu eder." $(\% 19,3)$, şeklinde olduğu görülmektedir. Aşağıda her bir kategorinin ayrı olarak betimsel analizine yer verilecektir.

\section{Kategori 1: "Şarkı söylemek insana özgürlük hissi verir."}

Bu kategoride, 29 öğrenci $(\% 19,3)$ tarafından, 'Şarkı söylemek insana özgürlük hissi verir.' ifadesiyle örtüşen 11 metafor tanımlanmıştır. En baskın olan metafor bu kategoridedir. $\mathrm{Bu}$ metaforlar: 'arınmak (f:1), haykırış (f:1), haykırmak (f:1), hedonizm (f:1), kendin olmak (f:1), kuş (f:1), nefes almak (f:3), özgürleşmek (f:2), özgürlük (f:14), sanat yapmak (f:1), uçmak (f:3)' şeklindedir. Frekans dağılımlarına göre en çok kullanılan metaforların; özgürlük, nefes almak, uçmak, özgürleşmek olduğu görülmektedir. Aşağıda en çok kullanılan metaforlara, kayıtlı form sırasına göre betimsel olarak bir kaç örnek verilmiştir. Örneğin;

Ö 37 : "Şarkı söylemek özgürlük gibidir. Çünkü; Söylediğimiz şarkıyı kendi istediğimiz şekilde özgürce söyleriz."

Ö 123: "Şarkı söylemek özgürlük gibidir. Çünkü; özgürlüğünü dışa vurmanın en iyi şeklidir.

Ö 149: “Şarkı söylemek özgürlük gibidir. Çünkü; sadece kendinlesin.”

Ö 111 : “Şarkı söylemek uçmak gibidir. Çünkü; uçmak insanı özgür hissettirir aynı özgürlük şarkı söylemek için de geçerlidir."

Ö 146: "Şarkı söylemek uçmak gibidir. Çünkü; Şarkı söylerken kendimi uçmuş gibi özgür hissederim."

Ö 21: "Şarkı söylemek kuş gibidir. Çünkü; Özgür hissettirir." 


\section{Kategori 2: "Şarkı söylemek bir rahatlama biçimidir."}

Bu kategoride, 23 öğrenci (\%22,7) tarafından, 'Şarkı söylemek bir rahatlama biçimidir.' ifadesiyle benzer 20 metafor tanımlanmıştır. Bu metaforlar: 'dertleşmek (f:1), deşarj olmak (f:1), deşarj (f:1), içimizi dökmek (f:1), içindekileri anlatmak (f:1), içini dökmek (f:5), ilaç (f:2), isyan etmek (f:1), iyileşmek (f:1), meditasyon (f:5), ruh (f:6), ruh hali (f:1), ruhun gidası (f:1), sağlık (f:1), stres atma (f:1), stres atmak (f:1), şifa kaynağı (f:1), uçsuz bucaksız dağa bağırmak (f:1), uyumak (f:1), yürüyüş yapmak (f:1)' şeklindedir. Frekans dağılımlarına göre en çok kullanılan metaforların; ruh, meditasyon, içini dökmek, ilaç olduğu görülmektedir. Aşağıda en çok kullanılan metaforlara, kayıtlı form sırasına göre betimsel olarak bir kaç örnek verilmiştir. Örneğin;

Ö 82: "Şarkı söylemek içini dökmek gibidir. Çünkü; rahatlatıcıdır."

Ö 139: “Şark1 söylemek meditasyon gibidir. Çünkü; ne zaman sıkılsam, bunalsam şarkı söylerim."

Ö 5: "Şarkı söylemek uyumak gibidir. Çünkü; şarkı söylediğimizde rahatlarız."

Ö 14: "Şarkı söylemek sağlık gibidir. Çünkü; strese iyi gelir."

Ö 138: “Şarkı söylemek ruh gibidir. Çünkü; ruhumuz açtır ve onu doyurmak şarkı söylemektir."

Ö 77: “Şarkı söylemek stres atma gibidir. Çünkü; şarkı söyleyince insanın bütün siniri ve sıkıntısı gider."

\section{Kategori 3: "Şarkı söylemek insanın duygularını yansıtır."}

Bu kategoride, 35 öğrenci (\%23,3) tarafından, 'Şarkı söylemek insanın duygularını yansıtır.' ifadesiyle benzer 31 metafor tanımlanmıştır. En fazla sayıda metafor bu kategoride toplanmıştır. Bu metaforlar: 'anlaşılmak (f:1), aşk (f:1), cesaret (f:1), coşku (f:1), coşmak (f:1), dışa vurmak (f:1), duyguları anlatmak (f:1), duygularımız (f:2), duyguları yansıtmak (f:1), duygularını dışa haykırmak (f:1), duygularını dışarı vurmak (f:1), duygularını haykırmak (f:1), duyguların ifade etmek (f:1), duyuları ifade etmek (f:1), hayal (f:1), hayal kurmak (f:1), hayat (f:2), hüzün (f:1), kahkaha atmak (f:1), kalbinin dillenip konuşması (f:1), kalp (f:1), kendini geliştirmek (f:1), konuşmak (f:1), korkusuzluktur (f:1), özgüven (f:1), rüzgâr (f:1), samimiyet (f:2), sevinç veya sıkıntıları paylaşmak (f:2), sevinmek (f:1), tablo yapmak (f:1), tutku (f:1)' şeklindedir. Frekans dağılımlarına göre en çok kullanılan metaforların; sevinç veya sıkıntıları paylaşmak, samimiyet, hayat ve duygularımız olduğu görülmektedir. Aşağıda en çok kullanılan metaforlara, kayıtlı form sırasına göre betimsel olarak bir kaç örnek verilmiştir. Örneğin;

Ö 61: “Şarkı söylemek samimiyet gibidir. Çünkü; şarkı söylerken kendi duygularımızı katarı."

Ö 13: “Şarkı söylemek hayat gibidir. Çünkü; hayattaki yaşadığımız duyguları şarkılara dökeriz."

Ö 100 : “Şarkı söylemek duygularımız gibidir. Çünkü; bazen sevinçli bazen üzülerek duygularımızı ne düşündügüumüzü ifade ederiz." 
Ö 12 : “Şarkı söylemek coşku gibidir. Çünkü; şarkı söylerken tüm duygularınızı dışarıya vurduğunuz için coşku gibidir."

Ö 33 : "Şarkı söylemek tablo yapmak gibidir. Çünkü; bir ressam nasıl tabloya boyayla fırçayla bir duygu veriyorsa bizde sesimizle bir duygu veririz."

\section{Kategori 4: "Şarkı söylemek eğlencelidir."}

Bu kategoride, 35 öğrenci (\%15,3) tarafından 'Şarkı söylemek eğlencelidir.' ifadesiyle benzer 15 metafor tanımlanmıştır. Bu metaforlar: 'araba kullanmak (f:1), araba sürmek (f:1), yüksekten denize atlamak (f:1), dans etmek (f:2), eğlence (f:1), eğlenceli (f:1), eğlencelidir (f:1), eğlenmek (f:6), lunapark (f:1), oyun (f:2), oyun oynamak (f:2), şarkıcılık (f:1), vuruşların birleşmesi (f:1), yazmayı yeni öğrenen çocuk (f:1), zevklidir (f:1)' şeklindedir. Frekans dağılımlarına göre en çok kullanılan; eğlenmek, oyun oynamak, dans etmek ve oyun metaforlarıdır. Aşağıda en çok kullanılan metaforlara, kayıtlı form sırasına göre betimsel olarak bir kaç örnek verilmiştir. Örneğin;

Ö 60: "Şarkı söylemek eğlenmek gibidir. Çünkü; söyledikçe daha çok söylersiniz aynı eğlenmek gibi."

Ö 107: "Şarkı söylemek oyun oynamak gibidir. Çünkü; eğlendirir.”

Ö 74: “Şarkı söylemek dans etmek gibidir. Çünkü; eğlendiriyor.

Ö 109 : “Şarkı söylemek oyun gibidir. Çünkü; ikisinde de çok eğlenirsin ve ikisinde de başka bir gerçeklikte gibi hissedersin."

Ö 69: "Şarkı söylemek çok yüksekten denize atlamak gibidir. Çünkü; heyecan verici ve eğlencelidir."

\section{Kategori 5: "Şarkı söylemek bizi mutlu eder."}

Bu kategoride ise 29 öğrenci (\%19,3) tarafından 'Şarkı söylemek bizi mutlu eder' ifadesiyle benzer 12 metafor tanımlanmıştır. Bu metaforlar: 'çiçek (f:1), çikolata (f:2), doğa yürüyüşü (f:1), gida (f:1), gülümsemek (f:1), kıyafet almak (f:1), mutlu olmak (f:1), mutluluk (f:3), paylaşmak (f:1), terapi (f:13), yaşamak (f:2), yemek (f:2)' şeklindedir. Frekans dağılımlarına göre en fazla kullanılan metaforlar; Terapi, mutluluk, yaşamak, yemek ve çikolata metaforlarıdır. Aşağıda en çok kullanılan metaforlara, kayıtlı form sırasına göre betimsel olarak bir kaç örnek verilmiştir. Örneğin;

Ö 148: “Şarkı söylemek terapi gibidir. Çünkü; söylerken kendini iyi hissetmeni sağlar."

Ö 113: “Şarkı söylemek yemek gibidir. Çünkü; insana canlılık katar.”

Ö 52: "Şarkı söylemek mutluluk gibidir. Çünkü; söyledikçe eğlenirim ve mutlu olurum."

Ö 36: "Şarkı söylemek yaşamak gibidir. Çünkü; Gününüz kötü de geçse şarkı söylediğiniz de mutlu olursunuz ve yaşadığınızı hissedersiniz."

Ö 83: "Şarkı söylemek çikolata gibidir. Çünkü; sevindirir.”

Ö 137: “Şarkı söylemek gülümsemek gibidir. Çünkü; insanı mutlu eder.” 


\section{Belirlenen kavramsal kategoriler öğrencilerin yaşı, sınıfı ve cinsiyeti açısından farklılık göstermekte midir?}

Tablo 6. "Müzik Dinlemek" kategorilerine ilişkin Cinsiyet, Sınıf Düzeyi ve Yaşa Göre Chi-Square Sonuçları

Cinsiyeti

\begin{tabular}{lccc}
\hline & Value & df & $\begin{array}{c}\text { A. Significance (2- } \\
\text { sided) }\end{array}$ \\
\hline Pearson Chi-Square & $35,109 \mathrm{a}$ & 4 &, 000 \\
\hline Likelihood Ratio & 34,877 & 4 &, 000 \\
\hline N of Valid Cases & 2426 & & \\
\hline Sinifi & & & \\
\hline
\end{tabular}

\begin{tabular}{lccc}
\hline & Value & df & $\begin{array}{c}\text { A. Significance (2- } \\
\text { sided) }\end{array}$ \\
\hline Pearson Chi-Square & $267,396 \mathrm{a}$ & 12 &, 000 \\
\hline Likelihood Ratio & 339,931 & 12 &, 000 \\
\hline N of Valid Cases & 2426 & & A. Significance (2- \\
\hline Yaşı & & & sided) \\
\hline & Value & $\mathrm{df}$ &, 000 \\
\hline Pearson Chi-Square & $363,357 \mathrm{a}$ & 16 &, 000 \\
\hline Likelihood Ratio & 429,632 & 16 &, 028 \\
\hline Linear-by-Linear Ass. & 4,806 & 1 & \\
\hline N of Valid Cases & 2426 & & \\
\hline
\end{tabular}

Kavramsal kategorilerin karşılaştırmasında çıkan sonuçlar doğrultusunda anlamlı farklılı̆̆ın olmadığı ortaya çıkmıştır.

\section{TARTIŞMA VE SONUÇ}

Burhaniye Anadolu Lisesi öğrencilerinin "Müzik dinlemek" ve şarkı söylemek kavramlarına ilişkin algılarının metaforlar aracılığı ile incelenmesiyle; Öğrenciler, "Müzik dinlemek...gibidir. Çünkü..." kavramına ilişkin 77 adet metafor üretmişlerdir. Bu metaforlar içerisinde en sık kullanılanların 'terapi $(\% 11,3)$, huzur $(\% 6,0)$, hayat $(\% 5,3)$, uyumak $(\% 4,7)$, dinlenmek $(\% 4,0)$ ve rahatlamak $(\% 4,0)^{\prime}$ metaforları olduğu tespit edilmiştir. Öğrencilerin bu metaforları açıklama nedenlerine bağlı olarak 5 kavramsal kategori elde edilmiştir. Elde edilen metaforlar, en yüksek oranda $(\% 38,7)$ Müzik dinlemek insanın ruhunu dinlendirir kategorisinde bulunmaktadır. Diğer frekans oranlarına göre sırasıyla; "Müzik dinlemek insana huzur ve mutluluk verir" (\%19,3), "Müzik dinlemek bir temel ihtiyaçtır" (\%19,3), "Müzik dinlemek rahatlatıcı ve eğlencelidir." (\%14), "Müzik dinlemek bir yaşam biçimidir." (\%8,7), şeklindedir. Öğrencilerin müzik dinlemek kavramını bireylerin kendi yaşamları doğrultusunda eğitim düzeyleri, aile ve gelişimleri doğrultusunda çok farklı metaforlarla tanımladıkları belirlenmiştir. Bu kategorilerden çıkan sonuçlara göre müzik dinlemenin bir yaşam biçimi olduğu, insanlara huzur ve mutluluk verdiği, sağlıklı bir birey olabilmesi için bir temel ihtiyaç olduğu aynı zamanda rahatlatan ve eğlenceli bir aktivite olduğu şeklinde belirgin 
metaforlarla ifade edilmesinde müzik dinlemenin önemli bir araç olarak gördükleri söylenebilir. Babacan (2014, s. 131) çalışmasında Anadolu Güzel Sanatlar Lisesi müzik öğrencilerinin "müzik" kavramına ilişkin geliştirdikleri metaforları 9 farklı kategoride toplanmıştır. Müzik kavramına ilişkin pek çok farklı metaforun üretildiğini belitmiş ve bunu müziğin kültürel bir öğe olduğu vurgulayarak her kültüre göre anlamının değişebileceğini belirtmiştir. Araştırma sonuçlarına göre müziğin huzur ve mutluluk veren, eğlenceli, çaba gerektiren, ihtiyaç duyulan gereksinim gibi kategorilerin bu araştırmayla paralellik gösterdiği görülmektedir.

Diğer kavramda ise Burhaniye Anadolu Lisesi öğrencilerinin "şarkı söylemek" kavramına ilişkin algılarının metaforlar aracılığı ile incelenmesiyle; Öğrenciler, "Şarkı Söylemek...gibidir. Çünkü..." kavramına ilişkin 89 adet metafor üretmişlerdir. Bu metaforlar içerisinde en sık kullanılan, 'özgürlük $(\% 9,3)$, terapi $(\% 8,7)$, eğlenmek (\%4), ruh (\%4) ve içini dökmek (\%3,3), meditasyon $(\% 3,3)$ metaforlarıdır. Öğrencilerin bu metaforları açıklama nedenlerine bağlı olarak 5 kavramsal kategori elde edilmiştir. Elde edilen metaforlar, en yüksek oranda $(\% 23,3)$ 'Şarkı söylemek insanın duygularını yansıtır' kategorisinde bulunmaktadır. Diğer kategoriler sırasıyla; "Şarkı söylemek insana özgürlük hissi verir." (\%19,3), "Şarkı söylemek bir rahatlama biçimidir." (\%22,7), "Şarkı söylemek eğlencelidir." (\%15,3), "Şarkı söylemek bizi mutlu eder." (\%19,3), şeklindedir. Kullanılan metaforlar arasında Çiçek (f:1), Çikolata (f:2), Doğa yürüyüşü (f:1), Gıda (f:1), Gülümsemek (f:1), Kıyafet almak (f:1), gibi metaforlara da rastlanmış anlam bütünlüğü olarak bakıldığında çünkü cevabı sonrasında, kendilerini mutlu hissettikleri metaforlarla ifade ettikleri anlaşılmıştır. Çünkü ile başlayan kavramda en sık kullanılan metaforlara bakıldığında genel tablo, kişinin kendini özgür hissetmesi, sıkıntılı anlarında bir rahatlama biçimi ve duyguları en iyi şekilde yansıtabilmelerini sağlayan, mutlu olmalarını bir araç olduğu imgelerden anlaşılmaktadır. Araştırmada, kavramsal kategorilerin cinsiyet, sınıf düzeyi ve yaşa göre karşılaştırılması yapılmıştır. SPSS programına girilen verilerle yapılan Chi-Square sonuçlarında anlamlı farklılığın olmadığı ortaya çıkmıştır. Mermi ve Aktay 2020 çalışmalarında ilkokul öğrencilerinin dinleme konuşma becerilerini incelemek amacıyla yaptıkları metaforik çalışma sonucunda, öğrencilerin dinlemeyi en çok işitme duyusu konuşmayı ise sesin dışa vurumu olarak algıladıkları çalışmada öğrencilerin bazıları "Müzik çalar çalıyor bizde dinliyoruz bu yüzden dinlemeyi müzik çalara benzetiyorum.", "Şarkı dinler gibi dinliyoruz." "Dinlemeyle müzik dinleme aynıdır" gibi ifadeler kullanıldığı görülmüştür. Dinlemeyle konuşmanın iç içe ve birbiriyle ilişkili olduğu, iyi dinlemenin iyi konuşmanın önemini vurgulanmıştır. Müzik eğitiminin de iyi bir dinleyici olma, güzel şarkı söyleme ile dil gelişimine katkıları olduğu bir gerçektir. Alanyazın ve örnek araştırmalar incelenerek alınan sonuçlar doğrultusunda, müzik dinlemenin ve şarkı söylemenin, hayatın vazgeçilmez bir parçası olduğu, adeta terapi gibi, özgürlük uyandıran, eğlenceli, mutluluk veren, gereksinimler olduğu söylenebilir. Buradan yola çıarak, genel müzik eğitimi derslerinde iyi bir müzik dinleyicisi yetiştirmek ve dil gelişimlerine katkı sağlamak adına müzik dinleme, koro ve ses eğitimi çalışmalarına sık yer verilmesi, niteliklerinin arttırılması önem taşımaktadır. 


\section{KAYNAKÇA}

Aktaş, Ş. \& Gündüz, O. (2004). Yazılı ve sözlü anlatım kompozisyon sanatı (5. baskl). Akçă̆ Yayınları.

Babacan, E. (2014). AGSL öğrencilerinin müzik kavramına ilişkin algıları: Metafor analizi. Ĕ̆itim ve Öğretim Araştırmaları Dergisi, 3(1),124-132.

Balc1, A. (1999). Metaphorical images of school: school perceptions of students, teachers and parents

from four selected schools (in Ankara). Doktora tezi, METU Institute of Social Sciences, Ankara.

Bilgin, N. (2006). Sosyal bilimlerde içerik analizi. Siyasal Kitabevi.

Buyurgan, S. \& Buyurgan, U. (2012). Sanat eğitimi ve öğretimi. Pegem A Yayıncılık.

Çetinkaya, Y. (2019). Müzik bölümü öğrencilerinin müzik kavramına ilişkin metaforik algıları. Ordu Üniversitesi Sosyal Bilimler Enstitüsü Sosyal Bilimler Araştırmaları Dergisi, 9(3), 539547. https://dergipark.org.tr/tr/pub/odusobiad/issue/50379/617243

Düzgören, H., \& Gerekten, E.S. (2017). Anadolu lisesi öğrencilerinin 'müzik dersi' kavramına ilişkin algıları: Metafor analizi. Çevrimiçi Müzik Bilimleri Dergisi, 2(3), 86-117. https://dergipark.org.tr/en/pub/ojomus/issue/33836/304548

Erdem, C. (2011). Ergenin müzikle iletişimi. Türk Pediatri Arşivi Dergisi, 46 Özel Sayı, 19-21.

Erol, A. (2009). Popüler müziği anlamak kültürel kimlik bağlamında popüler müzikte anlam. (3. basım). Bağlam Yayıncılık.

Inbar, D. E. (1996). The free educational prison. Metaphors and Images. Educational Research, 38(1), 77-92. https://doi.org/10.1080/0013188960380106

Kövecses, Z. (2010). Metaphor. Oxford University Press.

Lakoff, G. \& Johnson, M. (1980). Metaphors we live by. University of Chicago Press.

Martin, G., Clarke, M. \& Pearce, C. (1993). Adolescent suicide: music preference as an indicator of vulnerability. Journal of The American Academy of Child \& Adolescent Psychiatry, 32(3), 530-535.

Martinez, C. L. (2015). Active listening as the core method in teaching the elements of music. Alipato: A journal Basic Education, 6, 9-30.

Mermi, F. \& Aktay, G. E., (2020). İlköğretim öğrencilerinin dinleme ve konuşma becelerine ilişkin metaforik algıları. International Journal of Language Academy, 8(3),143/158. http://dx.doi.org/10.29228/ijla.42690

Miles, M. B. \& Huberman, A. M. (1994). Qualitative data analysis. Sage Publication.

Morgan, G. (1998). Yönetim ve örgüt teorilerinden metafor. BZD Yayınc1lık.

Örücü, D. (2012). İlköğretim sınıf öğretmenlerinin sınıfa ve sınıf yönetimine ilişkin metaforik bakışları: Karşılaştırmalı bir durum çalışması. Elementary Education Online, 11(2), 342352. https://dergipark.org.tr/en/pub/ilkonline/issue/8589/106738

Ritchie, L. D. (2013). Metaphor. Cambridge University Press. 
Saban, A. (2008). Okula ilişkin metaforlar. Kuram ve Uygulamada Eğitim Yönetimi, 55, 459-496. https://dergipark.org.tr/en/pub/kuey/issue/10342/126702

Saban, A. (2009). Öğretmen adaylarının öğrenci kavramına ilişkin sahip oldukları zihinsel $\begin{array}{llll}\text { imgeleri. Türk Eğitim Bilimleri Dergisi, } & 7(2), \quad 281-326 .\end{array}$ https://dergipark.org.tr/en/pub/tebd/issue/26107/275061

Tez, İ. \& Uygun, M. A. (2016). Ortaokul öğrencilerinin müzik dersi ve müzik öğretmenine ilişkin algılarının metaforik analizi. Kalem Eğitim ve İnsan Bilimleri Dergisi, 6(2), 417455 .

Türk Dil Kurumu (2011). Türkçe Sözlük. TDK Yayınları.

Umuzdaş, S. \& Umuzdaş, S. (2013). Sınıf öğretmenliği öğrencilerinin müzik dersine ilişkin algilarınin metaforlar yoluyla belirlenmesi. Internatinal Journal Of Human Science, 10(1), 719-729.

Uygun, M. A. (2015). Öğretmen adaylarının geleneksel müzik türlerine ilişkin algılarının metaforlar aracılığı ile incelenmesi. Afyon Kocatepe Üniversitesi Akademik Müzik Araştırmaları Dergisi, $1(1), \quad 1-16$. https://dergipark.org.tr/tr/pub/amader/issue/1724/21129

Yıldırım, A. \& Şimşek, H. (2000). Sosyal bilimlerde nitel araştırma yöntemleri. (2. Basım). Seçkin Yayınları.

Yıldırım, K. (2010). Nitel araştırmalarda niteliği arttırma. İlköğretim Online, 9(1), 79-92. https://dergipark.org.tr/tr/pub/ilkonline/issue/8596/106955

Yıldız, M. Y. \& Karakelle, S. (2017). İlköğretim dönemindeki çocukların müziksel gelişim özellikleri ve müzik eğitimi. Uluslararası Sosyal Araştırmalar Dergisi, 10(48), 494-500.

Yolcu, E. (2004). Sanat eğitimi kuramları ve yöntemleri. Nobel Yayınc1lık.

Zembat, R., Tunçeli, İ. H. \& Akşin, E. (2015). Okul öncesi öğretmen adaylarının “okul yöneticisi" kavramına ilişkin algılarına yönelik metafor çalışması. Hacettepe Üniversitesi Sağllk Bilimleri Fakültesi Dergisi, 1(2), 446-459. https://dergipark.org.tr/tr/pub/husbfd/issue/7893/103908

Zheng, H. \& Song, W. (2010). Metaphor analysis in the educational discourse: A critical review. Online Submission, US-China Foreign Language, 8(9), 42-49. https://dergipark.org.tr/tr/pub/husbfd/issue/7893/103908 